\title{
Diversity of methanotrophs in Zoige wetland soils under both anaerobic and aerobic conditions
}

\author{
Juanli Yun ${ }^{2}$, Anzhou Ma${ }^{1}$, Yaoming $\mathrm{Li}^{2}$, Guoqiang Zhuang ${ }^{1}$, \\ Yanfen Wang ${ }^{2}$, Hongxun Zhang ${ }^{2, *}$ \\ 1. Research Center for Eco-Environment Sciences, Chinese Academy of Sciences, Beijing 100085, China \\ 2. Graduate University of Chinese Academy of Sciences, Beijing 100049, China. E-mail: yunjuanli@ 126.com
}

Received 13 October 2009; revised 26 December 2009; accepted 03 March 2010

\begin{abstract}
Zoige wetland is one of the most important methane emission centers in China. The oxidation of methane in the wetland affects global warming, soil ecology and atmospheric chemistry. Despite their global significance, microorganisms that consume methane in Zoige wetland remain poorly characterized. In this study, we investigated methanotrophs diversity in soil samples from both anaerobic site and aerobic site in Zoige wetland using $p m o A$ gene as a molecular marker. The cloning library was constructed according to the $p m o A$ sequences detected. Four clusters of methanotrophs were detected. The phylogenetic tree showed that all four clusters detected were affiliated to type I methanotrophs. Two novel clusters (cluster 1, cluster 2) were found to relate to none of the recognized genera of methanotrophs. These clusters have no cultured representatives and reveal an ecological adaptation of particular uncultured methanotrophs in Zoige wetland. Two clusters were belonging to Methylobacter and Methylococcus separately. Denaturing gradient gel electrophoresis gel bands pattern retrieved from these two samples revealed that the community compositions of anaerobic soil and aerobic soil were different from each other while anaerobic soil showed a higher metanotrophs diversity. Real-time PCR assays of the two samples demonstrated that aerobic soil sample in Zoige wetland was 1.5 times as much copy numbers as anaerobic soil. These data illustrated that methanotrophs are a group of microorganisms influence the methane consumption in Zoige wetland.
\end{abstract}

Key words: cloning library; denaturing gradient gel electrophoresis; methanotrophs; pmoA gene; real-time PCR; Zoige wetland DOI: $10.1016 /$ S1001-0742(09)60243-6

\section{Introduction}

Zoige wetland of Tibetan Plateau is located at a low latitude region and under the annual temperature around $1^{\circ} \mathrm{C}$. Previous studies indicated that Zoige wetland was one of the $\mathrm{CH}_{4}$ emission centers in Qinghai-Tibetan Plateau (Jin et al., 1999), and the annual methane emission in Qinghai-Tibetan Plateau was estimated to be 0.56-1 Tg (Ding et al., 2004; Ding and Cai, 2007; Chen et al., 2008). Chen et al. (2008) recently reported that the mean methane emission rate of $14.45 \mathrm{mg} \mathrm{CH}_{4} /\left(\mathrm{m}^{2} \cdot \mathrm{hr}\right)(0.17-86.78 \mathrm{mg}$ $\left.\mathrm{CH}_{4} /\left(\mathrm{m}^{2} \cdot \mathrm{hr}\right)\right)$ was measured in Zoige wetland.

Wetlands in cold area, like permafrost and tundra, contribute a large proportion of global methane emission, as about $750 \%$ of Earth's biosphere is under permanently low temperature (Cavicchioli, 2006). It was shown that $15 \%$ to more than $90 \%$ of the diffusive methane flux in wetlands is oxidized by methane oxidizing bacteria (Roslev and King, 1996; Le Mer and Roger, 2001). Therefore, methantrophs play an important role in the wetland methane cycle (Conrad, 1996; Hanson and Hanson, 1996).

Methanotrophic communities were found to be abun-

\footnotetext{
* Corresponding author. E-mail: hxzhang@gucas.ac.cn
}

dant and active in cold environments such as, northern peat lands (Trotsenko and Khmelenina, 2005). It was recently shown that methane oxidizing bacteria are well adapted to the temperature regime in permafrost active layer (Liebner and Wagner, 2007). However, the study of diversity and composition of methanotrophs in Zoige wetland remains very poor.

According to previous studies, methanotrophs are an important group of methylotrophic bacteria (Bowman et al., 1993; Hanson and Hanson, 1996). Based on their cell morphology, ultra structure, phylogeny and metabolic pathways, methanotrophs can be divided into two taxonomic groups, Type I and Type II. Type I methanotrophs include Methylobacter, Methylomicrobium, Methylomonas, Methylocaldum, Methylosphaera, Methylothermus, Methylosarcina and Methylococcus, which belong to the $\gamma$-subdivision of Proteobacteria. The type II methanotrophs include Methylocystis, Methylosinus, Methylocella and Methylocapsa, which are in the $\alpha$-subdivision of Proteobacteria (Hanson and Hanson, 1996).

The process that oxidize methane into $\mathrm{CO}_{2}$ is always catalyzed by methane monooxygenase (MMO), there are 
two different forms of this enzyme: a membrane-bound particulate MMO (pMMO), which is present in almost all methanotrophs isolated so far, and the soluble form (sMMO), which has been found in only some methanotrophs (Murrell, 1992). pMMO is homologous to the ammonium monooxygenase (AMO), the key enzyme of AOB (Holmes et al., 1995). AMO catalyzes not only the oxidation of ammonia but also that of methane, although with a much lower activity (Bedard and Knowles, 1989).

The $p m o A$ gene encodes the active site polypeptide of particulate methane monooxygenase, a key enzyme in methane oxidation (Pacheco-Oliver et al., 2002). It has been used as a molecular marker in numerous environmental studies of methanotroph diversity (Murrell et al., 1998; Henckel et al., 1999; Fjellbirkeland et al., 2001; Horz et al., 2001) and is an ideal marker because it codes for an enzyme that is central to methane oxidation presenting in all known methanotrophs (with the exception of Methylocella). There is no evidence of horizontal transfer of pmoA among methanotrophs (Murrell et al., 1998; Costello and Lidstrom, 1999). The most important is that compare to $16 \mathrm{~S}$ ribosomal DNA (rDNA), the use of $p m o A$ as a marker for methanotrophs has clear advantages. In a study by Holmes et al. (1999), pmoA trees showed congruent clusters of methanotrophic genera compared to phylogenies based on 16S rDNA (Suzuki et al., 2000). By comparison, 16S rDNA-based assays may also detect nonmethanotrophic bacteria closely related to known methanotrophs.

In this study, we used $p m o A$ gene as a tool to investigate the diversity of metahnotrophs in soil samples from both anaerobic site and aerobic site in Zoige wetland. A phylogenetic tree based on the $p m o A$ gene was constructed to show the diversity of metahnotrophs. Community diversity and gene copy numbers were also detected in this study. We analyzed and compared the results with other data available for wetland soils.

\section{Materials and methods}

\subsection{Soil sampling}

The sampling site, Zoige wetland, is located at Tibetan Plateau at $33^{\circ} 56^{\prime} \mathrm{N}, 102^{\circ} 52^{\prime} \mathrm{E}$ and at an altitude of 3430 $3460 \mathrm{~m}$. The soil temperatures in the depth of $10-30 \mathrm{~cm}$ were measured between 6 and $15^{\circ} \mathrm{C}$ from June to September (Yang and Dong, 1993). The anaerobic soil sample was sampled from water flooded soil (M) and aerobic sample was sampled from surface soil (S) in the depth of 0 $20 \mathrm{~cm}$ at the end of July 2008. Anaerobic soil samples were maintained in sterile serum bottles capped with butyl rubber stopper, and then kept samples in ice box during transportation. Soil properties of two soil samples are listed in Table 1. All samples were stored at $-20^{\circ} \mathrm{C}$ before use.

\subsection{Extraction of total DNA}

Extraction of DNA from $0.5 \mathrm{~g}$ soil was performed using the ultra soil DNA extraction kit (MoBio Laboratories, Solana Beach, USA) according to the manufacturer's
Table 1 Properties of soil samples from Zoige wetland

\begin{tabular}{lll}
\hline & Anaerobic soil & Aerobic soil \\
\hline Water content $(\%)$ & 87.03 & 45.49 \\
$\mathrm{pH}$ & 6.18 & 5.87 \\
Total organic matter $(\%)$ & 60.80 & 57.49 \\
Total nitrogen $(\%)$ & 1.51 & 0.87 \\
Ammonium nitrogen $(\mathrm{mg} / \mathrm{kg})$ & 71.09 & 49.21 \\
Nitrate nitrogen $(\mathrm{mg} / \mathrm{kg})$ & 9.03 & 6.77 \\
\hline
\end{tabular}

instructions. The DNA was suspended in a final volume of $50 \mu \mathrm{L}$ and stored at $-20^{\circ} \mathrm{C}$. DNA quantification was performed with a Nanodrop ${ }^{\circledR}$ ND-1000 UV-Vis Spectrophotometer Technologies (Nanodrop Thecnologies, USA) according to the manufacturer's directions. The DNA yield was approximately 5 to $20 \mathrm{ng} / \mu \mathrm{L}$.

\subsection{PCR amplification}

The PCR amplification was performed with a thermal cycler (Eppendorf, Germany). The amplification of pmoA genes was performed via a PCR approach using the forward primer A189 (GGNGACTGGGACTTCTGG) and the reverse primer mb661 (CCGGMGCAACGTCYTTACC) (Lin et al., 2005).

The temperature profile was identical to the study of Zhang et al. (2008): initial denaturation at $94^{\circ} \mathrm{C}$ for $7 \mathrm{~min}$ followed by 30 cycles of denaturation at $94^{\circ} \mathrm{C}$ for $60 \mathrm{sec}$, annealing at $50^{\circ} \mathrm{C}$ for $45 \mathrm{sec}$ and extension at $72^{\circ} \mathrm{C}$ for $90 \mathrm{sec}$, and a final elongation at $72^{\circ} \mathrm{C}$ for $7 \mathrm{~min}$. PCR reaction mixture contains $5 \mu \mathrm{L}$ Taq buffer, $3 \mu \mathrm{L}$ dNTP (1.5 mmol/L, final concentration), $1 \mu \mathrm{L}$ of each primer $(0.4$ $\mathrm{mmol} / \mathrm{L}$, final concentration), $0.2 \mu \mathrm{L}$ BSA (10 mg/mL), 1 $\mu \mathrm{L}$ template DNA, $0.4 \mu \mathrm{L}$ Taq DNA polymerase $(5 \mathrm{U} / \mu \mathrm{L}$, Takara, Japan) and add RNase free $\mathrm{dH}_{2} \mathrm{O}$ (Takara, Japan) to a final volume of $50 \mu \mathrm{L}$. The PCR amplification products of approximately $500 \mathrm{bp}$ were checked using $1.0 \%$ agar gel.

\subsection{Denaturing gradient gel electrophoresis (DGGE)}

The $p m o A$ gene in DGGE was amplified with forward primer A189 with a GC clamp (Henckel et al., 1999) and a reverse primer mb661 (Knief et al., 2005). PCR amplification was performed as described in Section 1.3. PCR products were separated in 1-mm-thick polyacrylamide gels $(6.5 \%, W / \mathrm{V})$ acrylamide-bisacrylamide $(37.5: 1, \mathrm{~m} / \mathrm{m})$ using a linear denaturing gradient ranging from $25 \%$ to $65 \%$ in the Dcode System (Bio-Rad, Germany). Each sample was performed in triplicates. Gradient electrophoresis was performed in $1 \times$ TAE buffer constantly at $60 \mathrm{~V}$ for 16 $\mathrm{hr}$ at $60^{\circ} \mathrm{C}$. The gel was stained for $30 \mathrm{~min}$ with ethidium bromide (EB) and then scanned with AlphaEaseFC image system. A cluster analysis was performed based on the presence of difference bands showed in DGGE gel of PCR products amplified with A189GC and mb661. A matrix of similarities between the densitometric curves of the band patterns was calculated based on the Dice coefficient with Quantity One 4.5.2 software (Bio-Rad, Germany). Finally, the DGGE patterns were clustered based on the unweighted pair-group arithmetic average (UPGAMA) clustering 
algorithm.

\subsection{Quantification of methanotrophic bacteria by real- time PCR}

The real-time PCR amplification was carried out in Mx 3005P QPCR thermocycler (Stratagene, USA). All data analysis was performed with Mx Pro QPCR software (version 3.0, Stratagene, USA). Threshold cycle (TC) was determined from dilution series of target DNA with defined target molecule amounts by analysis of PCR kinetics on the Mx Pro QPCR software. TC value was proportional to the logarithm of the target molecule number. Thus, a TC value measured in a sample could be converted to a target molecule number. More details of real-time PCR are explained by Raeymaekers (2000) and Suzuki et al. (2000).

The temperature profile contained an initial denaturation at $94^{\circ} \mathrm{C}$ for $10 \mathrm{~min}$, followed by 40 cycles of denaturation at $95^{\circ} \mathrm{C}$ for $60 \mathrm{sec}$, annealing at $60^{\circ} \mathrm{C}$ for $30 \mathrm{sec}$ and extension at $72^{\circ} \mathrm{C}$ for $30 \mathrm{sec}$. The polymerase chain reaction was performed in $25 \mu \mathrm{L}$ volumes using special PCR tubes (Axygen, USA), reaction solutions contained 12.5 $\mu \mathrm{L}$ of MaximaTM SYBR Green Fluorescein qPCR Master Mix (Fermentas, USA), $0.5 \mu \mathrm{L}$ of each primer $(0.4$ $\mathrm{mmol} / \mathrm{L}$, final concentrations $), 0.2 \mu \mathrm{L} \mathrm{BSA}(10 \mathrm{mg} / \mathrm{mL}), 1$ $\mu \mathrm{L}$ of DNA extractions and $10.8 \mu \mathrm{L}$ of RNase free $\mathrm{dH}_{2} \mathrm{O}$ (Takara, Japan). The addition of bovine serum albumin as described by Kreader (1996) was to reduce inhibition by humic substances.

As for the calibration standard, clone M-5 inserted with pmoA was used to set up standard curve for realtime PCR. Plasmids were extracted using BioMed mini Plasmid Kit (BioDve-tech, China), and DNA samples were quantified by NanoDrop ${ }^{\circledR}$ ND-1000 UV-Vis Spectrophotometer (Nanodrop Thecnologies, USA). Copy numbers of plasmids were calculated according to Stubner (2002). The plasmids were then serially diluted to $10-10^{10}$ targeted molecules per microlitre and used to construct standard curves of pmoA gene copies for methanotrophs according to Kolb and colleagues (Kolb et al., 2003). All the measurements were performed in triplicates.

\subsection{Cloning and sequencing}

PCR products were purified with cycle pure kit (Omega, USA) and then ligated into pGEM-T easy vector (Promega, USA). Plasmids were transformed into competent DH5 $\alpha$ cells via heat shock following the manufacture's protocol. Cells were incubated at $37^{\circ} \mathrm{C}$ overnight on agar plates containing $0.05 \%$ Ampicillin. White clones were selected for Colony PCR. PCR profiles were the same as described previously in PCR amplification. The final volume of the mixture was $25 \mu \mathrm{L}$. The reactions were performed in 96 cells plate. PCR products were digested with Msp I (New England Biolabs, USA) subsequently according to the description of the manufacture (Horz et al., 2001) in order to avoid sequencing the same clone repetitiously. Digestion results were checked with $1.5 \%$ agar gel, and clones showed different bands were selected and sequenced.

\subsection{Phylogenetic analysis}

The identities of the pmoA gene sequences were confirmed by searching the international sequence databases using the BLAST programs (http://www. ncbi.nlm.nih.gov/BLAST). The best matching sequences were retrieved from the database and analyzed with CLUSTAL X (Thompson et al., 1994). The phylogenetic tree was constructed using neighbor-joining approach implemented in MEGA4 (Tamura et al., 2007). The topologies of the resultant tree were calculated by bootstrap analysis (Felsenstein, 1985) based on 1000 replications.

\subsection{Nucleotide sequence accession numbers}

Representative $p m o A$ nucleotide sequences obtained in this study have been deposited in Gene Bank database under the accession numbers GQ906775 to GQ906792 and GQ906793 to GQ906796.

\section{Results}

\subsection{Phylogenetic analysis of $\mathrm{pmoA}$ gene}

Cloning libraries were constructed using $p m o A$ genes from two soil samples. Figure 1 shows the phylogenetic affiliations of all clone sequences analyzed in our study. Four clusters (1, 2, 3 and 4) were formed distinctly. All of the four clusters belonged to the type I methanotrophs, within which cluster 3 and cluster 4 belonged to Methylobacter and Methylococcus respectively. Two sequences (M-2 and M-34) formed cluster 3, and were identified as genera Methylobacter. S-7 and M-5 were two sequences identical to Methylococcus (99\% similarity) and formed cluster 4. Cluster 2 was formed by two sequences (S-7 and S114) and dedicated a similarity of $99 \%$ to Methanotrophic proteobacterium. Most sequences detected in our study were clustered to cluster 1 , and several separated branches were formed in this group. S-11 and M-160 in this cluster showed a close similarity to proteobacterium (>95\%). The rest of sequences in this group formed four separated sub branches. Branch formed by M-33 and M-44 showed a similarity of $99 \%$ to each other. The same similarity revealed inner branch formed by M-4 and M-25, and also within branch formed by S-112 and S-34. M-159, M-115, M-40 and M-140 formed a distinct branch in cluster 1 and was distant from other recognized methanotrophs in the phylogenetic tree.

As we could see from the phylogenetic tree, the cloning library indicated that only type I methanotroph was detected in both aerobic and anaerobic soil samples and no type II methanotrophs were detected.

\subsection{DGGE analysis of methanotrphic diversity using pmoA gene}

A sum of 14 bands were detected in DGGE profile (Fig. 2a). The DGGE banding pattern of the two samples showed slightly difference. Nine of the fourteen bands (bands 3, 4, 6, 7, 8, 10, 11, 12 and 13) separated by DGGE were dominative bands in both samples. 1, 2 and 14 were special bands only presented in anaerobic sample 


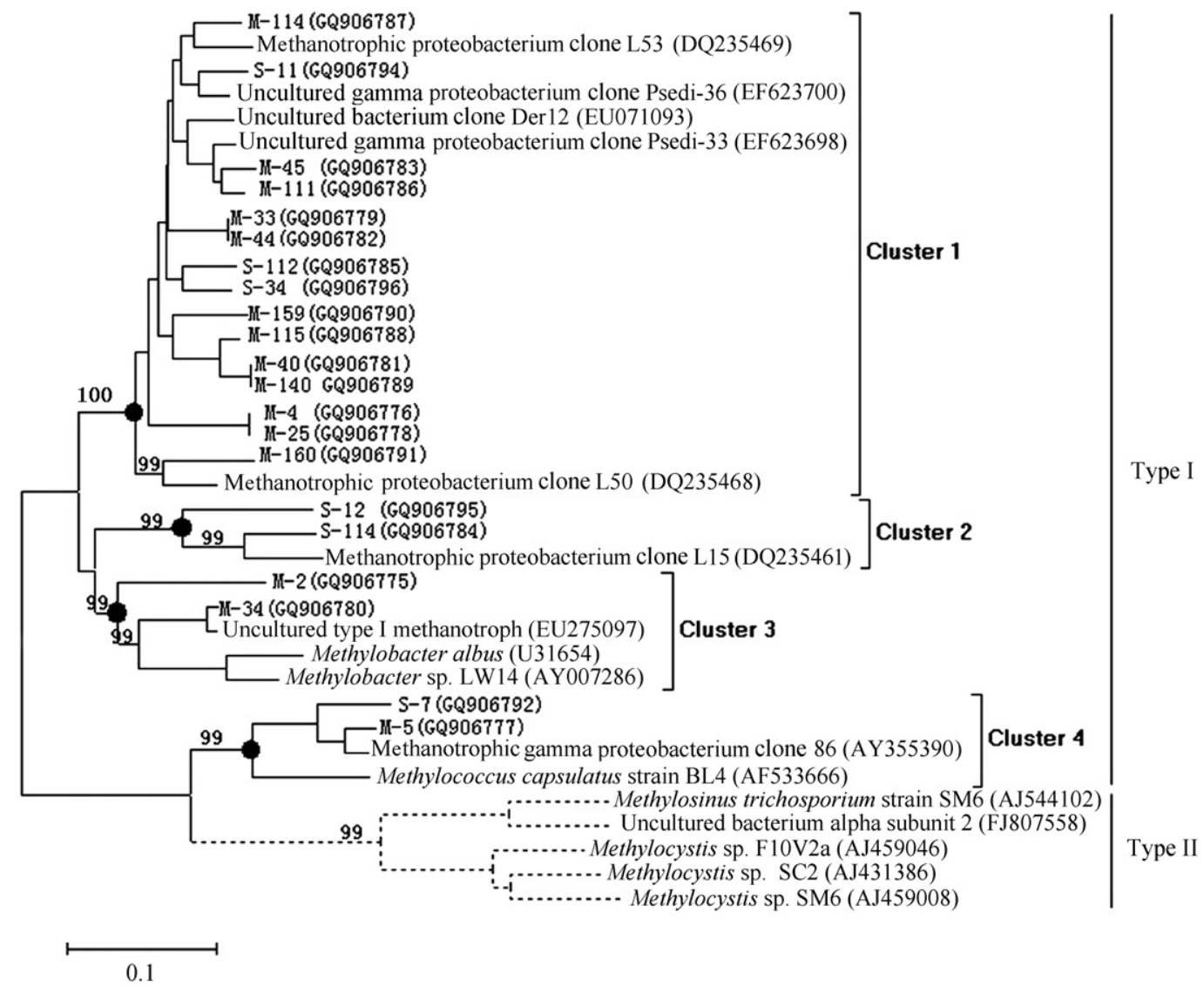

Fig. 1 Phylogenetic tree of $p m o A$ sequences retrieved from Zoige wetland. The tree was constructed using neighbour-joining approach. Bootstrap values greater than 98 are shown (100 replications). The bar represents 0.1 substitution per nucleotide position.
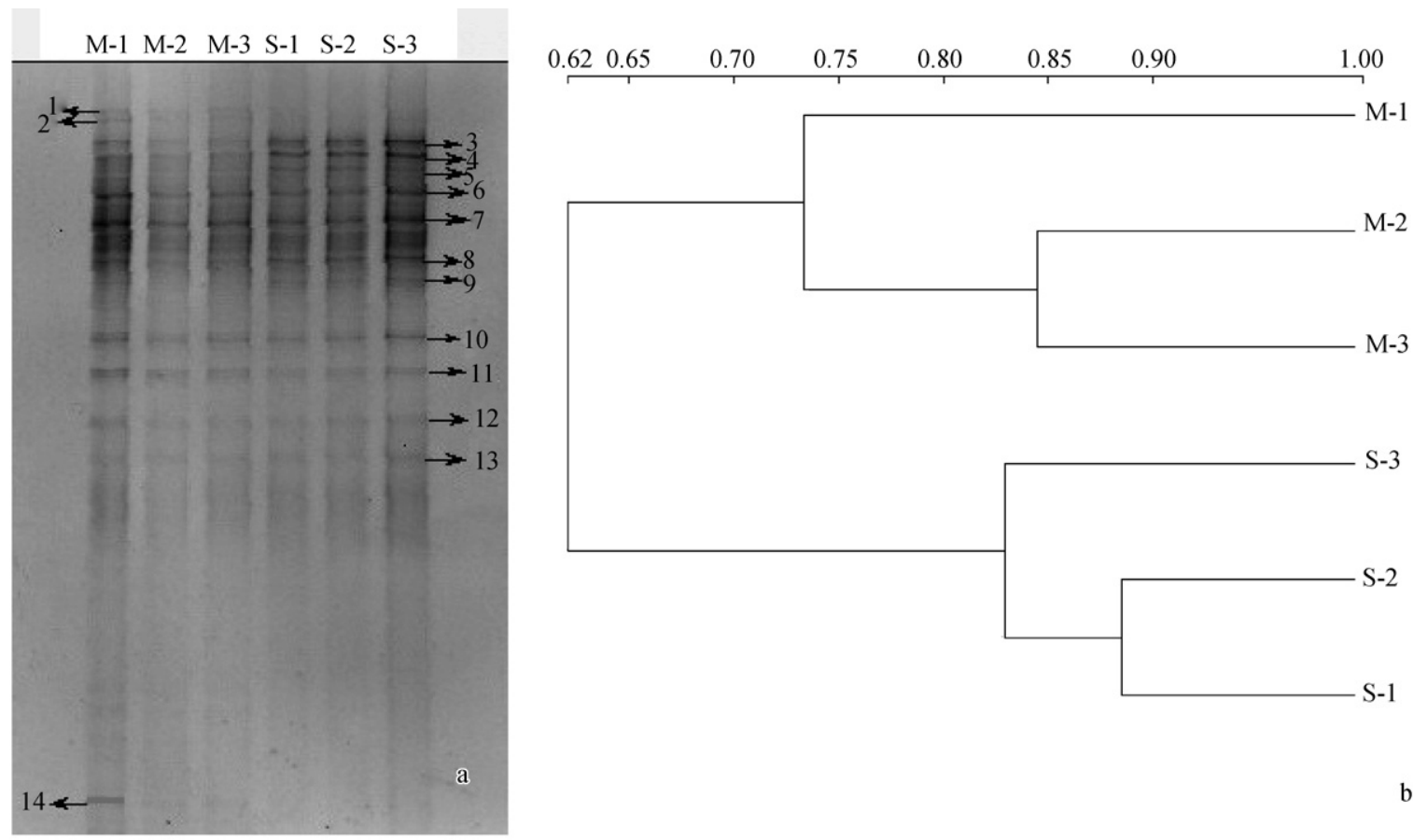

Fig. 2 DGGE results of PCR products. (a) DGGE profiles of methanotrophs from soil M and soil S. Both samples were amplified for triplicates with GC-A189-mb661, DNA bands detected were labeled beside lanes; (b) cluster analysis based on the DGGE gels. DGGE patterns were clustered based on the unweighted pair-group arithmetic average (UPGAMA) clustering algorithm.

(M) whereas bands 5 and 9 were two significant bands characterized in aerobic soil sample $(\mathrm{S})$. The total DGGE bands detected in $\mathrm{M}$ (12 bands) was one band more than detected in S (11 bands).

Cluster analyses (Fig. 2b) based on the DGGE profile showed that soil $\mathrm{M}$ and $\mathrm{S}$ had similar community 
compositions of methane-oxidizing bacteria and clustered together initially at a similarity of 0.62 . The replicates analyzed from each sample were very similar to each other. This demonstrated a good repetitiveness of this study. The replicates from all soil samples formed separate clusters.

\subsection{Real-time PCR assays}

Real-time PCR assays for quantification of pmoA copy number have been quantified with A189 and mb661 in both samples ( $\mathrm{M}$ and $\mathrm{S}$ ). The results of two samples were very different from each other. According to the data analysis of Mx Pro QPCR software (version 3.0, Stratagene, USA), the copy numbers were $(1.37 \pm 0.18) \times 10^{6}$ gene copies per gram dry weight of soil and $(2.08 \pm 0.22) \times 10^{6}$ gene copies per gram dry weight of soil in soil $\mathrm{M}$ and soil $\mathrm{S}$ respectively. The calculation of gene copy numbers were mean $\pm \operatorname{SE}(n=3)$.

\section{Discussion}

To give a comprehensive understanding of the diversity of methanotrophs in Zoige wetland, we sampled two kinds of soils including water flooded soil (M), which represents anaerobic soils, and surface soil (S), which stands for aerobic soils.

All the clusters detected (cluster 1, 2, 3 and 4) were confirmed to affiliate to type I methanotrophs. And recognized ones within the type I were related to only two know genera, Methylobacter and Methylococcus (Hanson and Hanson, 1996). But apparently, none of the two genera dominated. Cluster 1 was the dominate community in Zoige wetland and so far, all sequences detected in cluster 1 have been restricted to Zoige wetland soils. For the first time, this special group of methanotrophs in such extreme environment had been investigated. But none of these sequences belonged to species that could be cultivated. It is hard to explore their physical characteristics. We need effective approaches to give more information about them.

A study on high-arctic sediments based on DGGE profiles found the methanotrophs were also restricted to two genera, Methylobacter and Methylosarcina. But in that study, both type I and type II were detected (Wartiainen et al., 2003). Another study on Siberia showed the same results to our study that type II methanotrophs were not detected, and similarly, only two genera, Methylobacter and Methylosarcina were presented in the study. And within these two genera, Methylobacter was dominated (Liebner et al., 2009).

We used mb661 as reverse primer to detect the diversity of methanotrophs in our study because there was a report showed that the A189-mb661 PCR primer set demonstrated the highest methanotroph diversity of all of the primer sets (Bourne et al., 2001). Therefore, it is not the primer we used resulted in a low diversity of methanotrophs. It is probably because the low abundance of type II methanotrophs in samples. According to this, we would have detected type II if their abundance was high enough. The reason to the unsuccessfully amplification of type II could be due to the bias of PCR. In the procedure of PCR, type II was artificially biased owning to the low abundance in our samples (Liebner et al., 2009).

Previously studies have reported that the methane oxidation rate decreased under increased soil moisture, it's reasonable that reduced oxidizing rate could lead to a decrease of microbe abundance (Whalen et al., 1990; Adamsen and King, 1993; Castro et al., 1995). A study on methanotrophs in a California Upland Grassland soil dedicated the same conclusion with these studies. It also observed a significant decrease in type II methanotrophs in response to an increase of temperature (Horz et al., 2005). The sampling time of our study was in the end of July, which was the warmest time of the year. The temperature can significantly increase the soil water content due to the plant community transpiration (Zavaleta et al., 2003). Therefore, a better diversity of methanotrophs could be retrieved from Zoige wetland according to the water content of soil samples in dry season.

Furthermore, type II methanotrophs became relatively more abundant as methane concentrations increased (Macalady et al., 2002). One possible explanation is that the soil moisture can lead to negative effects on methane diffusion and increase anoxic microcosmos in soil, which can consequently increase the methanogenesis. With the methane concentration fell, the diversity and abundance of methanotrophs decreased at the same time (Horz et al., 2005).

The resulted cluster diagram according to DGGE gel pattern obviously confirmed the high similarity of replicates from one sample and differences between two soil samples (Fig. 2). The differences within the PCR amplifications from one sample were due to the faint DGGE bands visible in one replicate but not in the other replicate. Therefore, abundance of the pmoA sequences near the detection limit of analysis methods were the main groups that responsible for the dissimilarity of triplicate PCR products. There was a slightly difference among the three PCR replicates of the same sample. All the replicates are very close to each other. However, the main purpose of the cluster analysis in our study was to compare the differences between anaerobic and aerobic soil samples. Two samples from different sites showed differences in community composition due to the different bands detected in DGGE gel. Sample M showed a higher diversity than S according to the DGGE banding pattern. The differences of methanotrophic diversity between two soil samples could be probably understood by the different environment conditions where they survive. Soil $\mathrm{M}$ was sampled from anaerobic site and soil $\mathrm{S}$ was retrieved from aerobic site of Zoige wetland. The concentration of oxygen would be a significant factor that influenced the diversity of methanotrophs. It is hard to explain how oxygen concentration influenced the methanotrophic diversity. We need further study to explore the relationship between them.

Another reasonable explanation to the increased methanotrophs diversity in anaerobic soils in Zoige wetland is temperature. Zoige wetland was famous for its low temperature all year around. The temperature in water flooded soil was even lower than that of aerobic soil. 
Hence, it was the special low temperature in anaerobic soil that contributed to the higher diversity of methanotrophs. Compare to a previously study in Siberia (Liebner et al., 2009), in which only two dominant bands were detected, DGGE study here showed a much higher methanotrophs diversity.

Real-time PCR provides a more specific, sensitive, and reproducible measure of the initial amount of template sample and is preferable to other forms of quantitative PCR, which only detect the final amount of amplified product. With real-time PCR, fluorescence emission is monitored during the reaction as an indicator of amplicon production during each PCR cycle (Franks et al., 1998). For the first time, gene copies of methanotrophs were detected in this area using cultivation-independent method. Real-time PCR assays targeting methanotrophs is a promising way to elucidate the structure of methanotrophic communities in natural habitat. This new method overcome the disadvantages of traditional methods such as MPN and FISH in the aspects of biases by selective culture conditions and requires too much manual effort to obtain statistically significant values in soil.

Real-time PCR using SybrGreen as the detection system revealed that methanotrophs in Zoige wetland were about $10^{6} \mathrm{pmoA}$ gene copies per gram dry weight of soil in both samples. The actual number of metanotrophic bacteria cells should be low, because there were at least two pmoA copies can be expected per cell (Stolyar et al., 1999). The results of our study showed a equivalent gene copies with the study of Kolb et al. (2003), they found $5.0 \times$ $10^{6}$ gene copies per gram dry weight of soil in a flooded rice field. And again, in a later study, Kolb et al. (2005) detected $10^{6}$ gene copies per gram dry weight of soil of methanotrophs in a forest soil. Both of these two studies based on the methods of real-time PCR. While the gene copy number showed no differences with other studies, we could conclude that the extreme environment in Zoige wetland had no significant influence on the quantity of methanotrophs.

The copy numbers of methane oxidation bacteria in aerobic surface soil $\mathrm{S}$ was 1.5 times as much as anaerobic soil M. A reliable explanation for this phenomenon was that methanotrophs are a group of aerobic bacteria which use oxygen as an electron acceptor to oxidize methane (Hanson and Hanson, 1996). Water content in soil M was nearly 2 times that in soil S. Higher water content in soil would result in a relative anaerobic condition. Therefore, a lower level of water content was apparently more suitable for the growth of bacteria of this group. It is reasonable that $\mathrm{S}$ dedicated a higher gene copy number of $p m o A$.

\section{Conclusions}

In this study, we present first data on the diversity and abundance of methanotrophs in Zoige wetland. The cloning library based on pmoA genes revealed a community of methanotrophs that is specialized to the extreme environment it is exposed to. Two known genera were detected in this area. DGGE gel banding patterns indicated a highly community diversity in Zoige wetland compared to previous studies. Data of gene copy numbers of $p m o A$ gene were identical to other non extreme environments. This indicates a high level of adaption to low temperature of methanotrophs communities in Zoige wetland. All the results reported in this study are an initial investigation into the methanotrophs that contributes to further understanding of methane consumption in Zoige wetland.

\section{Acknowledgments}

This work was supported by the Knowledge Innovation Grant of the Chinese Academy of Sciences (No. kzcx2yw-418-03).

\section{References}

Adamsen A P S, King G M, 1993. Methane consumption in temperate and sub-arctic forest soils-rates,vertical zonation, and responses to water and nitrogen. Applied and Environmental Microbiology, 59(2): 485-490.

Bedard C, Knowles R, 1989. Physiology, biochemistry, and specific inhibitors of $\mathrm{CH}_{4}, \mathrm{NH}_{4}{ }^{+}$, and $\mathrm{CO}$ oxidation by methanotrophs and citrifiers. Microbiological Reviews, 53(1): 68-84.

Bourne D G, McDonald I R, Murrell J C, 2001. Comparison of pmoA PCR primer sets as tools for investigating methanotroph diversity in three Danish soils. Applied and Environmental Microbiology, 67(9): 3802-3809.

Bowman J P, Sly L I, Nichols P D, Hayward A C, 1993. Revised taxonomy of the methanotrophs-description of Methylobacter gen-nov, emendation of Methylococcus, validation of Methylosinus and Methylocystis species, and a proposal that the family Methylococcaceae includes only the group-I methanotrophs. International Journal of Systematic Bacteriology, 43(4): 735-753.

Castro M S, Steudler P A, Melillo J M, Aber J D, Bowden R D, 1995. Factors controlling atmospheric methane consumption by temperate forest soils. Global Biogeochemical Cycles, 9(1): $1-10$.

Cavicchioli R, 2006. Cold-adapted archaea. Nature Reviews Microbiolology, 4(5): 331-343.

Chen H, Yao S P, Wu N, Wang Y F, Luo P, Tian J Q et al., 2008. Determinants influencing seasonal variations of methane emissions from alpine wetlands in Zoige Plateau and their implications. Journal of Geophysical Research, 113, D12303. DOI: 10.1029/2006JD008072.

Conrad R, 1996. Soil microorganisms as controllers of atmospheric trace gases $\left(\mathrm{H}_{2}, \mathrm{CO}, \mathrm{CH}_{4}, \mathrm{OCS}, \mathrm{N}_{2} \mathrm{O}\right.$, and $\left.\mathrm{NO}\right)$. Microbiolological Reviews, 60(4): 609-640.

Costello A M, Lidstrom M E, 1999. Molecular characterization of functional and phylogenetic genes from natural populations of methanotrophs in lake sediments. Applied and Environmental Microbiology, 65(11): 5066-5074.

Ding W X, Cai Z C, 2007. Methane emission from natural wetlands in China: Summary of years 1995-2004 studies. Pedosphere, 17(4): 475-486.

Ding W X, Cai Z C, Wang D X, 2004. Preliminary budget of methane emissions from natural wetlands in China. Atmospheric Environment, 38(5): 751-759.

Felsenstein J, 1985. Confidence-limits on phylogenies - an approach using the bootstrap. Evolution, 39(4): 783-791.

Fjellbirkeland A, Torsvik V, Ovreas L, 2001. Methanotrophic diversity in an agricultural soil as evaluated by denaturing gradient gel electrophoresis profiles of pmoA, mxaF and 16S rDNA 
sequences. Antonie Van Leeuwenhoek, 79(2): 209-217.

Franks A H, Harmsen H J, Raangs G C, Jansen G J, Schut F, Welling G W, 1998. Variations of bacterial populations in human feces measured by fluorescent in situ hybridization with group-specific $16 \mathrm{~S}$ rRNA-targeted oligonucleotide probes. Applied and Environmental Microbiology, 64(9): 3336-3345.

Hanson R S, Hanson T E, 1996. Methanotrophic bacteria. Microbiolological Reviews, 60(2): 439-471.

Henckel T, Friedrich M, Conrad R, 1999. Molecular analyses of the methane-oxidizing microbial community in rice field soil by targeting the genes of the $16 \mathrm{~S}$ rRNA, particulate methane monooxygenase, and methanol dehydrogenase. Applied and Environmental Microbiology, 65(5): 1980-1990.

Holmes A J, Costello A, Lidstrom M E, Murrell J C, 1995. Evidence that participate methane monooxygenase and ammonia monooxygenase may be evolutionarily related. FEMS Microbiology Letters, 132(3): 203-208.

Holmes A J, Roslev P, McDonald I R, Iversen N, Henriksen K, Murrell J C, 1999. Characterization of methanotrophic bacterial populations in soils showing atmospheric methane uptake. Applied and Environmental Microbiology, 65(8): 3312-3318.

Horz H P, Rich V, Avrahami S, Bohannan B J, 2005. Methaneoxidizing bacteria in a California upland grassland soil: diversity and response to simulated global change. Applied and Environmental Microbiology, 71(5): 2642-2652.

Horz H P, Yimga M T, Liesack W, 2001. Detection of methanotroph diversity on roots of submerged rice plants by molecular retrieval of pmoA, mmoX, mxaF, and 16S rRNA and ribosomal DNA, including $p m o A$-based terminal restriction fragment length polymorphism profiling. Applied and Environmental Microbiology, 67(9): 4177-4185.

Jin H J, Wu J, Cheng G D, Tomoko N, Sun G Y, 1999. Methane emissions from wetlands on the Qinghai-Tibet Plateau. Chinese Science Bulletin, 44(24): 2282-2286.

Knief C, Vanitchung S, Harvey N W, Conrad R, Dunfield P F, Chidthaisong A, 2005. Diversity of methanotrophic bacteria in tropical upland soils under different land uses. Applied and Environmental Microbiology, 71(7): 3826-3831.

Kolb S, Knief C, Dunfield P F, Conrad R, 2005. Abundance and activity of uncultured methanotrophic bacteria involved in the consumption of atmospheric methane in two forest soils. Environmental Microbiology, 7(8): 1150-1161.

Kolb S, Knief C, Stubner S, Conrad R, 2003. Quantitative detection of methanotrophs in soil by novel pmoA-targeted real-time PCR assays. Applied and Environmental Microbiology, 69(5): 24232429.

Kreader C A, 1996. Relief of amplification inhibition in PCR with bovine serum albumin or $\mathrm{T} 4$ gene 32 protein. Applied and Environmental Microbiology, 62(3): 1102-1106.

Le Mer J, Roger P, 2001. Production, oxidation, emission and consumption of methane by soils: A review. European Journal of Soil Biology, 37(1): 25-50.

Liebner S, Rublack K, Stuehrmann T, Wagner D, 2009. Diversity of aerobic methanotrophic bacteria in a permafrost active layer soil of the Lena Delta, Siberia. Microbial Ecology, 57(1): 2535 .

Liebner S, Wagner D, 2007. Abundance, distribution and potential activity of methane oxidizing bacteria in permafrost soils from the Lena Delta, Siberia. Environmental Microbiology, 9(1): $107-117$.

Lin J L, Joye S B, Scholten J C M, Schafer H, McDonald I R, Murrell $\mathrm{J} \mathrm{C}, 2005$. Analysis of methane monooxygenase genes in mono lake suggests that increased methane oxidation activity may correlate with a change in methanotroph community structure. Applied and Environmental Microbiology, 71(10): 6458-6462.

Macalady J L, McMillan A M, Dickens A F, Tyler S C, Scow K M, 2002. Population dynamics of type I and II methanotrophic bacteria in rice soils. Environmental Microbiology, 4(3): 148157.

Murrell J C, 1992. Genetics and molecular biology of methanotrophs. FEMS Microbiology Reviews, 8(3-4): 233-248.

Murrell J C, McDonald I R, Bourne D G, 1998. Molecular methods for the study of methanotroph ecology. FEMS Microbiology Ecology, 27(2): 103-114.

Pacheco-Oliver M, McDonald I R, Groleau D, Murrell J C, Miguez C B, 2002. Detection of methanotrophs with highly divergent pmoA genes from Arctic soils. FEMS Microbiology Letters, 209(2): 313-319.

Raeymaekers L, 2000. Basic principles of quantitative PCR. Molecular Biotechnology, 15(2): 115-122.

Roslev P, King G M, 1996. Regulation of methane oxidation in a freshwater wetland by water table changes and anoxia. FEMS Microbiology Ecology, 19(2): 105-115.

Stolyar S, Costello A M, Peeples T L, Lidstrom M E, 1999. Role of multiple gene copies in particulate methane monooxygenase activity in the methane-oxidizing bacterium Methylococcus capsulatus Bath. Microbiology, 145 (5): 1235-1244.

Stubner S, 2002. Enumeration of 16S rDNA of Desulfotomaculum lineage 1 in rice field soil by real-time PCR with SybrGreen $^{\mathrm{TM}}$ detection. Journal of Microbiological Methods, 50(2): 155164.

Suzuki M T, Taylor L T, DeLong E F, 2000. Quantitative analysis of small-subunit rRNA genes in mixed microbial populations via 5 '-nuclease assays. Applied and Environmental Microbiology, 66(11): 4605-4614.

Tamura K, Dudley J, Nei M, Kumar S, 2007. MEGA4: molecular evolutionary genetics analysis (MEGA) software version 4.0. Molecular Biology and Evolution, 24(8): 1596-1599.

Thompson J D, Higgins D G, Gibson T J, 1994. CLUSTAL W: improving the sensitivity of progressive multiple sequence alignment through sequence weighting, position-specific gap penalties and weight matrix choice. Nucleic Acids Research, 22(22): 4673-4680.

Trotsenko Y A, Khmelenina V N, 2005. Aerobic methanotrophic bacteria of cold ecosystems. FEMS Microbiology Ecology, 53(1): 15-26.

Wartiainen I, Hestnes A G, Svenning M M, 2003. Methanotrophic diversity in high arctic wetlands on the islands of Svalbard (Norway)-denaturing gradient gel electrophoresis analysis of soil DNA and enrichment cultures. Canadian Journal of Microbiology, 49(10): 602-612.

Whalen S C, Reeburgh W S, Sandbeck K A, 1990. Rapid methane oxidation in a landfill cover soil. Applied and Environmental Microbiology, 56(11): 3405-3411.

Yang F, Dong Z, 1993. Study of the environment and ecology of wetland, meadow in Zoige Plateau. Journal of Sichuan Grassland, 14: 1-7.

Zavaleta E S, Thomas B D, Chiariello N R, Asner G P, Shaw M R, Field C B, 2003. Plants reverse warming effect on ecosystem water balance. Proceedings of National Academy of Sciences of United States of America, 100(17): 9892-9893.

Zhang G S, Tian J Q, Jiang N, Guo X P, Wang Y F, Dong X Z, 2008. Methanogen community in Zoige wetland of Tibetan Plateau and phenotypic characterization of a dominant uncultured methanogen cluster ZC-I. Environmental Microbiology, 10(7): 1850-1860. 